\title{
Are macrophyte-dwelling Chironomidae (Diptera) largely opportunistic in selecting plant species?
}

\author{
MónIKA TÓTH ${ }^{1}$, ARNOLD MÓRA ${ }^{1}$, BÉla KISS ${ }^{2}$, GYÖRGY DÉVAI ${ }^{3}$ and ANDRÁS SPECZIÁR ${ }^{1}$ \\ ${ }^{1}$ Balaton Limnological Research Institute of the Hungarian Academy of Sciences, H-8237 Tihany, Klebelsberg Kuno u. 3, Hungary; \\ e-mail: tothmoni@tres.blki.hu \\ ${ }^{2}$ BioAqua Pro Ltd., Soó Rezső u. 21, H-4032 Debrecen, Hungary \\ ${ }^{3}$ Department of Hydrobiology, Faculty of Science and Technology, University of Debrecen, Egyetem tér 1, H-4032 Debrecen, \\ Hungary
}

Key words. Chironomidae, macrophytes, habitat preference, vegetation pattern, environmental variables, backwater

\begin{abstract}
In this study we evaluate how variations in taxonomic composition and physical structure of macrophyte stands affect plant-dwelling chironomid assemblages in highly variable macrophyte assemblages in two densely vegetated backwaters. By using multivariate explanatory techniques we found that similar vegetation composition did not unequivocally relate to similar chironomid assemblages, moreover the diversity of macrophyte stands did not correlate with the taxonomic diversity of chironomid assemblages in the backwaters investigated. Taxonomic composition and structural characteristics of the vegetation had little influence on the taxonomic or functional (i.e. feeding groups) composition of chironomid assemblages inhabiting them. Similarly, there are only weak relationships between the distribution of certain chironomid species or functional feeding groups and the environmental variables investigated. In general, the structure of the vegetation was more closely associated with the distribution of dominant chironomid taxa than compositional variables (i.e. density of specific macrophyte taxa). In summary, the structure of aquatic vegetation (i.e. position, size of a stand of vegetation, total plant density) and characteristics of the environment where it develops may be more important in shaping plant-dwelling chironomid assemblages than the taxonomic composition of the vegetation.
\end{abstract}

\section{INTRODUCTION}

Macro-vegetation is an important and complex habitat in aquatic ecosystems, and influences species diversity and composition of macro-invertebrate communities in several ways (Cheruvelil et al., 2002; Bogut et al., 2007; Papas, 2007; Cremona et al., 2008; Bogut et al., 2010). Aquatic macro-vegetation provides invertebrates with a living place and shelter from predation and disturbance, and a good surface for epiphytic algae, which are important food sources for aquatic animals (Papas, 2007). Several authors record that morphology of plants (Krecker, 1939; Harrod, 1964; Ali et al., 2007), the area of plant surface that is colonisable (Dvorak \& Best, 1982; Cyr \& Downing, 1988), seasonal changes in the pattern (Scheffer et al., 1984) or the biomass of vegetation (van den Berg et al., 1997) cause differences in the composition, density and diversity of plant-dwelling macroinvertebrate communities. Whereas others argue that the physical conditions in vegetated habitats, such as water depth (Soszka, 1975a) or velocity of flowing water (Harrod, 1964), trophic status (Pieczynska et al., 1999) and the chemical nature of the vegetation (Harrod, 1964; Cyr \& Downing, 1988), and/or the quantity and quality of the available periphyton communities as a food source (Harrod, 1964; Cyr \& Downing, 1988; Balci \& Kennedy, 2003) could be more important in shaping the distribution of aquatic invertebrates, than the taxonomic composition of macrophyte stands.
Although there are many papers dealing with environmental influences on plant-dwelling macro-invertebrate communities, the taxonomic resolution of such studies are often limited, especially those on non-biting midges (Diptera: Chironomidae), which are commonly just classified to family or subfamily (but see e.g. Dvorak \& Best, 1982; van den Berg et al., 1997). However, chironomid larvae are one of the most dominant members of plant-dwelling macro-invertebrate communities and may show a distinct preference for a certain type of substratum (Armitage et al., 1995). The preference of chironomid larvae for different substrates is reviewed by Pinder (1986), who mentions that aquatic plants are one of the most important substrates for these organisms. Other authors report a positive relationship between the distribution of macrophyte beds and the abundance, diversity and spatiotemporal distribution of chironomids (Dvorak \& Best, 1982; Drake, 1983; Tokeshi \& Pinder, 1985; Armitage et al., 1995). Macrophyte density and diversity, as well the percentage of a whole lake covered with vegetation influence chironomid density, taxonomic richness (i.e. number of taxa identified) and relative abundance of chironomid functional guilds both on a seasonal and long-term scale, including historic trends (Brodersen et al., 2001; Tarkowska-Kukuryk \& Kornijów, 2008; Langdon et al., 2010). Chironomids avoid certain species of macrophyte and the distribution of especially their mining larvae (i.e. those living under the epidermis of leaves and stems of aquatic plants) is influenced by plant morphology (Kondo 


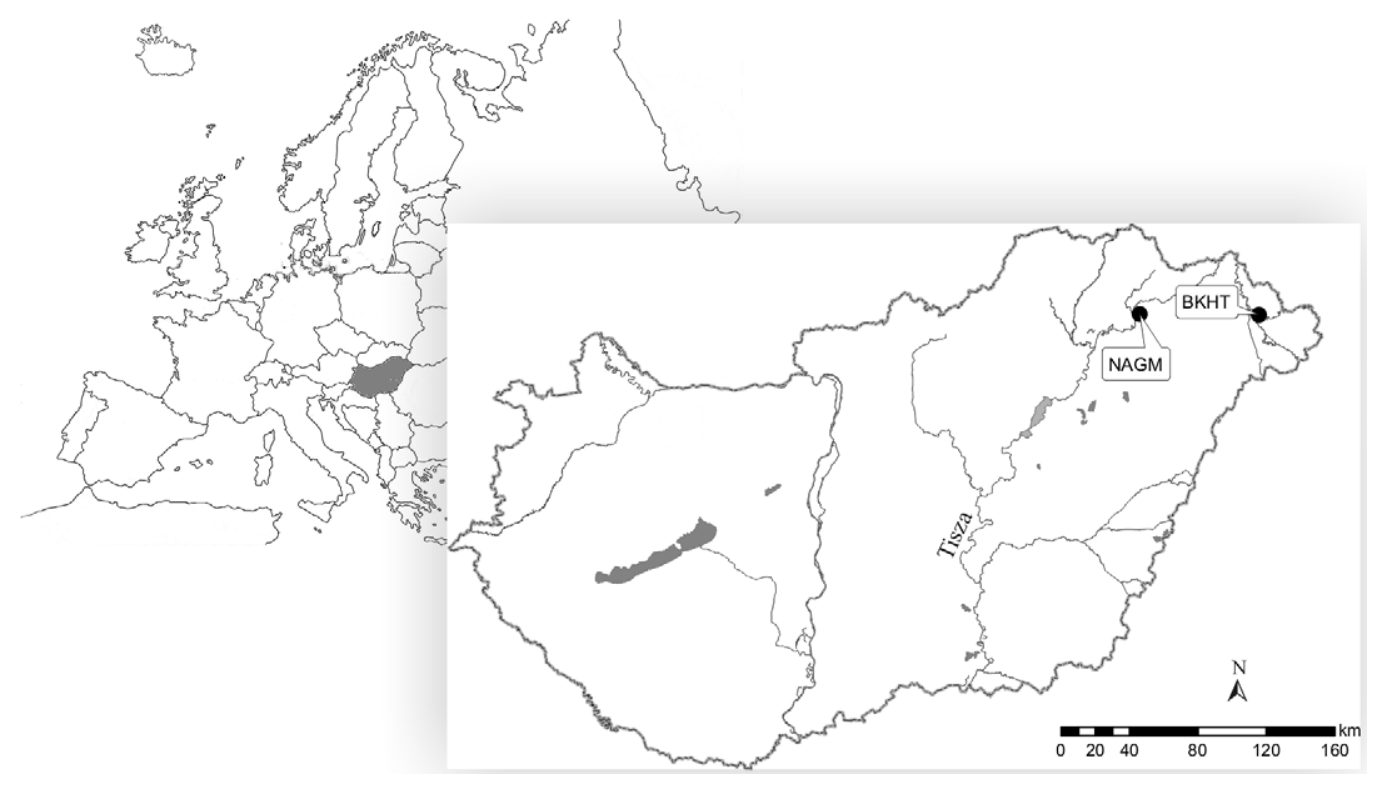

Fig. 1. Location of the Boroszló-kerti-Holt-Tisza (BKHT) and Nagy-morotva (NAGM) backwaters in Hungary.

\& Hamashima, 1992; Dvorak, 1996). In addition, seasonal changes or variations in lake trophic status or other environmental factors may have a greater effect on plantdwelling chironomid assemblages than the structure of the vegetation (van den Berg et al., 1997; Pieczynska et al., 1999; Balci \& Kennedy, 2003; Tarkowska-Kukuryk, 2006). However, it is still largely unknown, how variations in plant species composition within macrophyte stands affect chironomid assemblages at the same spatial scale.

The aim of this study was to analyse variations in chironomid assemblages living on macrophytes and determine how macrophyte assemblage structure affects the composition, abundance of the dominant species and functional feeding groups in chironomid assemblages. Unlike previous studies, the stands of vegetation were not a priory categorized based on their dominant plant species, but were treated as variable associations of different macrophyte taxa. To the best of our knowledge macrophytechironomid interactions have not been previously analysed using this approach. Previous studies deal mainly with chironomid assemblages associated with certain species of macrophyte (Dvorak, 1996; Balci \& Kennedy, 2003; Tarkowska-Kukuryk, 2006) or different types of macrophyte stands without considering the variability in their fine-scale composition (Trivinho-Strixino et al., 2000; Tarkowska-Kukuryk \& Kornijów, 2008). However, the macrophyte stands investigated were composed of dynamic mixtures of one or a few dominant and some less abundant species of plants rather than homogenous stands. We studied the association between variations in taxonomic composition and physical structure of macrophyte stands and plant-dwelling chironomid assemblages in two densely vegetated backwaters with highly variable macrophyte assemblages. Our specific objectives were: (1) to assess whether similarities among macrophyte assemblages are mirrored by similarities among chironomid assemblages, and (2) whether the diversity of chironomids increases with the diversity of macrophytes; (3) to analyse which macrophyte related environmental parameters are important in shaping chironomid assemblages; and (4) in influencing the abundance of dominant chironomid species or functional feeding groups.

\section{MATERIAL AND METHODS}

\section{Study sites}

This study was conducted on two backwaters, the Boroszlókerti-Holt-Tisza (BKHT) and Nagy-morotva (NAGM), both located in the Upper-Tisza region, NE Hungary (Fig. 1).

The BKHT $\left(48^{\circ} 05^{\prime} 10^{\prime \prime} \mathrm{N} ; 22^{\circ} 24^{\prime} 41^{\prime \prime} \mathrm{E}\right)$ was artificially established during the regulation of River Tisza in the $19^{\text {th }}$ century when the course of the river was straightened in order to shorten the periods of flooding and decrease the area flooded (Lászlóffy, 1982). The BKHT is a younger pond, which is connected to the River Tisza and regularly receives fresh water when the river floods. Its area is $14 \mathrm{ha}$, and it is $2.2 \mathrm{~km}$ long, on average $62 \mathrm{~m}$ wide and $1 \mathrm{~m}$ deep. During this investigation its shore was covered by a diversity of marshy vegetation dominated by Typha angustifolia L., Schoenoplectus lacustris (L.) Palla and Sparganium erectum L., and the pond was covered with patches of submerged and floating leaved macrophytes composed mainly of Ceratophyllum demersum L., Trapa natans L. and Nymphaea alba L., and to a smaller extent Potamogeton lucens L., Potamogeton crispus L. and Stratiotes aloides L.

The NAGM $\left(48^{\circ} 06^{\prime} 46^{\prime \prime} \mathrm{N} ; 21^{\circ} 28^{\prime} 34^{\prime \prime} \mathrm{E}\right)$ was established naturally when the river spontaneously cut across a bend. This pondlike backwater is not in direct connection with the river and receives fresh water only during extreme flooding or when it is artificially pumped from the river. Its area is 90 ha, and it is 4.4 $\mathrm{km}$ long, on average $205 \mathrm{~m}$ wide and $<1 \mathrm{~m}$ deep. At the time of the investigation the shore of the NAGM was covered by marshy vegetation composed of Typha angustifolia, Typha latifolia L., Schoenoplectus lacustris, Phragmites australis (Cavan.) Trin. et Stend. and Sparganium erectum, and the bottom was overgrown with submerged and floating leaved macrophytes, such as Ceratophyllum demersum, Trapa natans, Hydrocharis morsus-ranae L. Nymphaea alba and Stratiotes aloides. 


\section{Sample collection and processing}

Samples were collected in August 1999 when the biomass and cover of vegetation was at their maximum, using the close-andharvest method at 25 and 24 macrophyte covered sites at BKHT and NAGM, respectively. Sampling sites were chosen at random and were representative of all the characteristic macrophyte assemblages in the two backwaters. The units of habitat sampled were isolated using an aluminium cylinder enclosing an area of $0.5 \mathrm{~m}^{2}$ and 1 or $2 \mathrm{~m}$ long depending on the depth of the water. The lower edge of the cylinder was sharpened in order to cut the roots of plants and enable to penetrate into the sediment ensuring complete isolation of the sample and so preventing the escape of animals. Water depth was measured inside the cylinder to determine the volume of each sample. All plants and animals were collected from the sampler using a hand-net (mesh size $0.25 \mathrm{~mm}$ ) taking a special care not to disturb the sediment and organisms living there (Tóth et al., 1998; Nagy et al., 2001).

All samples were characterized by environmental parameters representing the size of the vegetation stand $\left(\mathrm{m}^{2}\right)$, water depth $(\mathrm{m})$, distance from the shore $(\mathrm{m})$, distance from the nearest area of open water (m) (i.e. macrophyte free area in the pond)), vegetation cover $(\%)$ and total vegetation density $\left(\mathrm{g} \mathrm{m}^{-3}\right.$, in fresh weight). The size of the vegetation stand and distances from the nearest area of open water and the shore were measured in the field, while vegetation cover was estimated visually by the same person at all sites.

Samples were immediately sorted in the field. Macrophytes were determined to species level and their fresh mass measured to the nearest $1 \mathrm{~g}$. Chironomid larvae were preserved in $70 \%$ ethyl-alcohol and transported to the laboratory for later identification. Chironomids were mounted on microscope slides and identified to the lowest possible taxonomic level using the keys of Bíró (1981), Cranston (1982), Wiederholm (1983), Janecek (1998), Vallenduuk (1999), Sæther et al. (2000) and Vallenduuk \& Moller Pillot (2002). The nomenclature of Sæther \& Spies (2004) was used. Abundance of chironomids was expressed as the number of individuals per sample volume (ind. $\mathrm{m}^{-3}$ ) and density of each species of macrophyte as plant mass per sample volume $\left(\mathrm{g} \mathrm{m}^{-3}\right)$.

\section{Statistical analysis}

Data on the chironomid assemblages were analyzed in terms of both taxonomic (i.e. mostly species level) and functional (i.e. feeding groups) levels. Chironomids were sorted into six guilds based on the morphology of their mouthparts, feeding behaviour and the food resource utilized according to Moog (2002). The guilds (Moog, 2002) were shredders (feeding on plant tissues and coarse particulate organic matter), grazers (feeding on epilithic algae, biofilm and partially particulate organic matter), active filter-feeders (feeding on suspended fine particulate organic matter), detritus feeders (feeding on fine particulate organic matter in the sediment), miners (feeding on leaves of aquatic plants and algae) and predators (feeding on invertebrates).

Chironomid abundance data were $\log (\mathrm{x}+1)$ transformed for the canonical correspondence analysis (CCA) and multiple linear regression analyses (MRA), and the relative abundance data were used to calculate chironomid assemblage diversity for each sample and among samples assemblage similarities (see below). Taxonomic richness (i.e. number of taxa) data were not transformed.

Environmental data were sorted into two groups. Macrophyte assemblage data (i.e. taxonomic composition of vegetation stands) formed the first group, the "compositional" variables, and the other measured variables (size of vegetation stand, water depth, distance from the shore, distance from the nearest area of open water, vegetation cover and total vegetation density) formed the second group, the "structural" variables. Macrophytes were classified in one of seven categories as follows: Ceratophyllum demersum, Hydrocharis morsus-ranae, Nymphaea alba, Potemogeton spp. (including P. crispus and $P$. lucens), Stratiotes aloides, Trapa natans and emerged marshy vegetation (including Phragmites australis, Schoenoplectus lacustris, Sparganium erectum, Typha angustifolia and T. latifolia). Merging of some plant taxa into common groups was needed because of their low density and/or sporadic occurrence. Relative abundance data were used to calculate macrophyte assemblage diversity for each sample and among samples assemblage similarities (see below). For other analyses, macrophyte density data were $\log (\mathrm{x}+1)$, while percentage vegetation cover data were $\arcsin \left[(\mathrm{x} / 100)^{0.5}\right]$ transformed to decrease the weight of extra high density values and to secure normality. Other environmental variables were not transformed.

Means of chironomid abundance and vegetation attribute data were compared between BKHT and NAGM using Student's t-tests, except for the percentage vegetation cover, which was compared using a Mann-Whitney U-test.

Variance in chironomid data were first analysed at the assemblage level. To explore whether similar macrophyte stands are inhabited by similar chironomid assemblages, among sample similarity matrixes of chironomid and macrophyte assemblages relative abundance data were compared using the Mantel test based on Bray-Curtis similarity measure and the PAST software package (Hammer et al., 2001). Then, to test whether higher macrophyte diversity is coupled with higher chironomid diversity, the relationship between the Shannon diversities of chironomid and macrophyte assemblages was analysed using Spearman rank correlation in Statistica 8.0 (Statsoft, Inc.).

Relationships between the taxonomic composition of chironomid assemblages and environmental variables were investigated using the CCA in CANOCO version 4.5 (ter Braak \& Śmilauer, 1998). Rare chironomid taxa occurring in less than three samples were excluded from the CCA analyses. Prior to analyses environmental variables were tested for colinearity using the Pearson correlation analysis in Statistica 8.0 (StatSoft, Inc.). Among variable correlations suggested that most environmental variables, including the macrophyte abundance data, were largely independent and only the depth of the water was not included in CCA analyses of the data for BHKT because of its strong $(R>0.5)$ correlation with several other environmental variables. The relative contribution of each variable to the whole model was assessed using the forward stepwise selection procedure, and their significance tested using a Monte-Carlo permutation test and 499 permutations of the full model. Similarly, the statistical significance of the ordination axes and the whole model (i.e. including all axes) were tested using a Monte Carlo permutation test and 499 permutations. In the CCA analysis of NAGM data based on chironomid functional feeding groups, one sample clearly separated from the others and as a consequence was not included the final analysis.

Finally, the effect of type of macrophyte ("compositional" variables) and other environmental variables ("structural" variables) on specific abundant chironomid taxa and guilds, as well on chironomid taxonomic richness and total chironomid density were explored using multiple linear regression analysis (MRA) and variance partitioning method (Borcard et al., 2004). Separate MRAs were run using the two environmental variable groups (i.e. "compositional" and "structural" variables) and when both were significant the two sub-models were combined into an overall MRA model. Variable selection in the submodels was based on the forward stepwise selection procedure and only variables with significant contributions (at $P<0.05$ ) 
TABLE 1. Abbreviations and values [mean, SD (standard deviation) and range] of the environmental variables associated with stands of vegetation in the Boroszló-kerti-Holt-Tisza (BKHT) and Nagy-morotva (NAGM) backwaters, Hungary. Between backwater differences in the variables were tested using paired t-test and Mann-Whitney U-test (in case of vegetation cover) and statistical differences are indicated as follows: * $P<0.05, * * P<0.01, * * * P<0.001$.

\begin{tabular}{|c|c|c|c|c|c|}
\hline \multirow{2}{*}{ Environmental variables } & \multirow{2}{*}{ Abbreviation } & \multicolumn{2}{|c|}{ BKHT } & \multicolumn{2}{|c|}{ NAGM } \\
\hline & & Mean (SD) & Range & Mean (SD) & Range \\
\hline \multicolumn{6}{|l|}{ Structural variables } \\
\hline total vegetation density $\left(\mathrm{g} \mathrm{m}^{-3}\right)$ & vegdens * & $846(583)$ & $135-2480$ & $1368(950)$ & $325-4270$ \\
\hline vegetation cover $(\%)$ & $\operatorname{cover} * *$ & $64(28)$ & $20-100$ & $85(14)$ & $40-100$ \\
\hline size of the sampled vegetation stand $\left(\mathrm{m}^{2}\right)$ & vegsize & $56(112)$ & $1-550$ & $2120(6138)$ & $12-30000$ \\
\hline water depth (m) & depth & $0.82(0.40)$ & $0.31-1.75$ & $0.87(0.33)$ & $0.22-1.31$ \\
\hline distance from the shore $(\mathrm{m})$ & disshore $* * *$ & $10(11)$ & $1-40$ & $45(27)$ & $2-110$ \\
\hline distance from the nearest area of open water (m) & disopen * & $6(8)$ & $0-35$ & $38(56)$ & $1-200$ \\
\hline \multicolumn{6}{|l|}{ Compositional variables (Plant taxa) } \\
\hline Ceratophyllum demersum $\mathrm{L} .\left(\mathrm{g} \mathrm{m}^{-3}\right)$ & cer dem & $770(1144)$ & $0-3817$ & $972(1794)$ & $0-8132$ \\
\hline Hydrocharis morsus-ranae L. $\left(\mathrm{g} \mathrm{m}^{-3}\right)$ & hyd mra & 0 & 0 & $177(437)$ & $0-1895$ \\
\hline Nymphaea alba L. $\left(\mathrm{g} \mathrm{m}^{-3}\right)$ & nym alb & $151(352)$ & $0-1379$ & $248(557)$ & $0-2263$ \\
\hline Phragmites australis (Cavan.) Trin. et Stend. $\left(\mathrm{g} \mathrm{m}^{-3}\right)$ & phr aus & 0 & 0 & $258(1262)$ & $0-6182$ \\
\hline Potamogeton crispus $\mathrm{L} .\left(\mathrm{g} \mathrm{m}^{-3}\right)$ & pot cri & $3(16)$ & $0-82$ & 0 & 0 \\
\hline Potamogeton lucens $\mathrm{L} .\left(\mathrm{g} \mathrm{m}^{-3}\right)$ & pot luc & $51(172)$ & $0-650$ & 0 & 0 \\
\hline Schoenoplectus lacustris (L.) Palla. $\left(\mathrm{g} \mathrm{m}^{-3}\right)$ & sch lac & 77 (389) & $0-1943$ & 0 & 0 \\
\hline Sparganium erectum L. $\left(\mathrm{g} \mathrm{m}^{-3}\right)$ & spa ere & $524(1891)$ & $0-8417$ & 0 & 0 \\
\hline Stratiotes aloides L. $\left(\mathrm{g} \mathrm{m}^{-3}\right)$ & str alo & $607(1272)$ & $0-4484$ & $592(1202)$ & $0-4863$ \\
\hline Trapa natans $\mathrm{L} .\left(\mathrm{g} \mathrm{m}^{-3}\right)$ & tra nat & $189(414)$ & $0-1538$ & $273(455)$ & $0-1524$ \\
\hline Typha angustifolia $\mathrm{L} .\left(\mathrm{g} \mathrm{m}^{-3}\right)$ & typ ang & $268(1085)$ & $0-5300$ & $183(623)$ & $0-2371$ \\
\hline Typha latifolia L. $\left(\mathrm{g} \mathrm{m}^{-3}\right)$ & typ lat & 0 & 0 & $184(902)$ & $0-4417$ \\
\hline
\end{tabular}

were retained. In the overall models all significant variables from the corresponding sub-models were retained. Partitioning of variation between the "compositional" and "structural" variable groups was based on adjusted $\mathrm{R}^{2}$ values $\left(R_{a d j .}^{2}\right)$ of the three MRA models (i.e. compositional sub-model, structural submodel and overall model) following Legendre (2008). Again, in order to avoid colinearity the depth of the water was not included in the analyses of the BHKT data. MRAs were performed in Statistica 8.0 software (StatSoft, Inc.).

\section{RESULTS}

\section{Environmental conditions}

Mean water depth (t-test, $t=-0.47, P=0.640$ ) and area of the vegetation stands sampled (t-test, $t=-1.68, P=$ $0.099)$ was similar $(<1 \mathrm{~m})$ in the two backwaters. However, other "structural" variables had significantly higher mean values in NAGM than BKHT (Table 1), reflecting that the macrophyte stands were on average larger and denser in NAGM.

In both backwaters, the areas sampled were dominated by the macrophytes Ceratophyllum demersum and Stratiotes aloides, and also by Sparganium erectum at BKHT. However, Potamogeton spp., Schoenoplectus lacustris and Sparganium erectum occurred only at BKHT and Phragmites australis, Typha latifolia and Hydrocharis morsus-ranae only at NAGM (Table 1; Figs 2-3). In general, the macrophyte associations were species rich and only $C$. demersum at NAGM and $N$. alba at BKHT formed monospecific stands (Figs 2-3).
In both backwaters, both "structural" and "compositional" vegetation characteristics varied markedly among the sites sampled, which provided long enough environmental gradients for vegetation-chironomid relationship analyses.

\section{Chironomid assemblages associated with macrophytes}

Altogether 34 chironomid taxa (Table 2) from three subfamilies (Tanypodinae: 6, Orthocladiinae: 1 and Chironominae: 27) were identified. Eighteen taxa occurred in both backwaters, while 12 taxa were found only at BKHT and 4 taxa only at NAGM. At BKHT three species made up more than half $(56 \%)$ of the total abundance: Polypedilum sordens (30\%), Kiefferulus tendipediformis (15\%) and Glyptotendipes pallens (11\%). At NAGM Glyptotendipes cauliginellus (14\%), Endochironomus tendens (12\%), Chironomus luridus gr. (10\%), Chironomus (Lobochironomus) dorsalis (11\%) and Glyptotendipes pallens $(10 \%)$ were the most abundant species. Mean total density of chironomids was two times higher at BKHT (86 ind. $\mathrm{m}^{-3}$ ) than NAGM (40 ind. $\mathrm{m}^{-3}$ ), but this difference was not statistically significant (t-test, $t=1.98$, $P=0.054)$.

Each functional feeding group (shredders, grazers, active filter-feeders, detritus feeders, miners and predators) occurred in both backwaters, of which the active filter-feeders, detritus feeders and grazers predominated (Figs 2-3). 


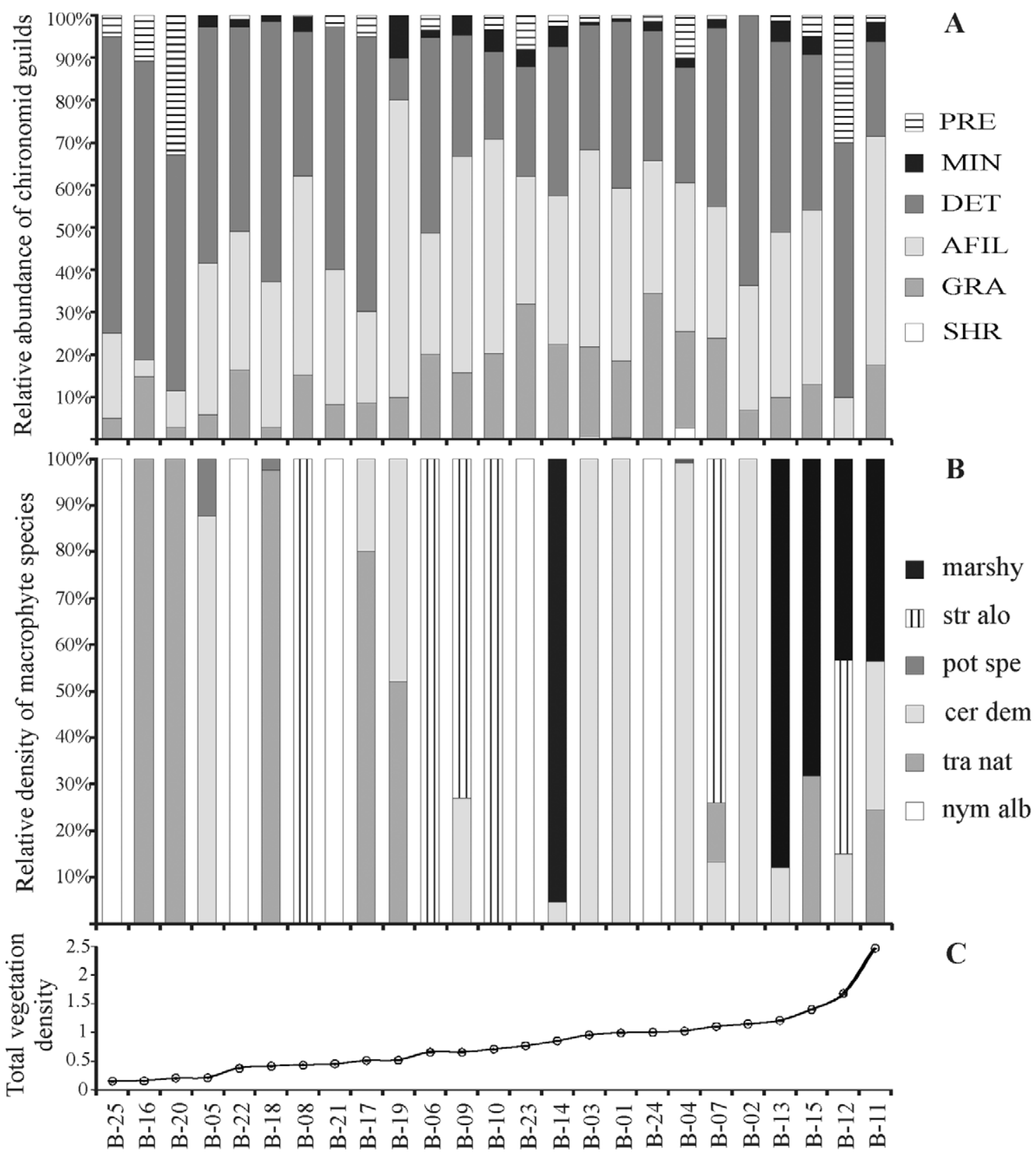

Fig. 2. Relative abundance of chironomid functional feeding guilds (A) and density of macrophyte species (B) recorded at the sites sampled in the Boroszló-kerti-Holt-Tisza (BKHT) backwater, Hungary, with the sites sampled sorted along a gradient of increasing vegetation density $\left(\mathrm{kg} \mathrm{m}^{-3}\right)(\mathrm{C})$. List of the abbreviations of plant species is given in Table 1, while abbreviations of functional feeding groups are: SHR = shredders, GRA = grazers, DET = detritus feeders, AFIL = active-filter feeders, MIN = miners and PRE $=$ predators.

\section{Assemblage level effect of vegetation on chironomids}

Chironomid and macrophyte assemblage data correlated in the BKHT (Mantel test, $R=0.322, P<0.001$ ), but not in the NAGM $(R=-0.004, P=0.499)$ suggesting that similar chironomid assemblages do not necessarily associate with similar vegetation even within a small system. Moreover, the taxonomic diversity of chironomid assemblages did not correlate with the diversity of macrophyte associations at BKHT (Spearman rank correlation, $R=0.119, P=0.057)$ or NAGM $(R=0.073, P=0.730)$.

CCA also did not reveal any unequivocal relationship between vegetation attributes and chironomid assemblage composition either at a taxonomic or functional level. Only one of the four CCA analyses (i.e. species/functional feeding group $\times$ two backwaters) had significant explanatory power, but only in the overall model (i.e. all axes) and not for any single axis (Fig. 4).

For BKHT, the CCA resulted in a statistically significant overall model explaining $60.6 \%$ of the total variance in the data but none of the derived ordination axes were significant. The first two CCA ordination axes explained $44.1 \%$ of the relation in the species-environment data and $26.7 \%$ of the variance in species data (Fig. 4). Forward selection procedure resulted in three significant "compo- 


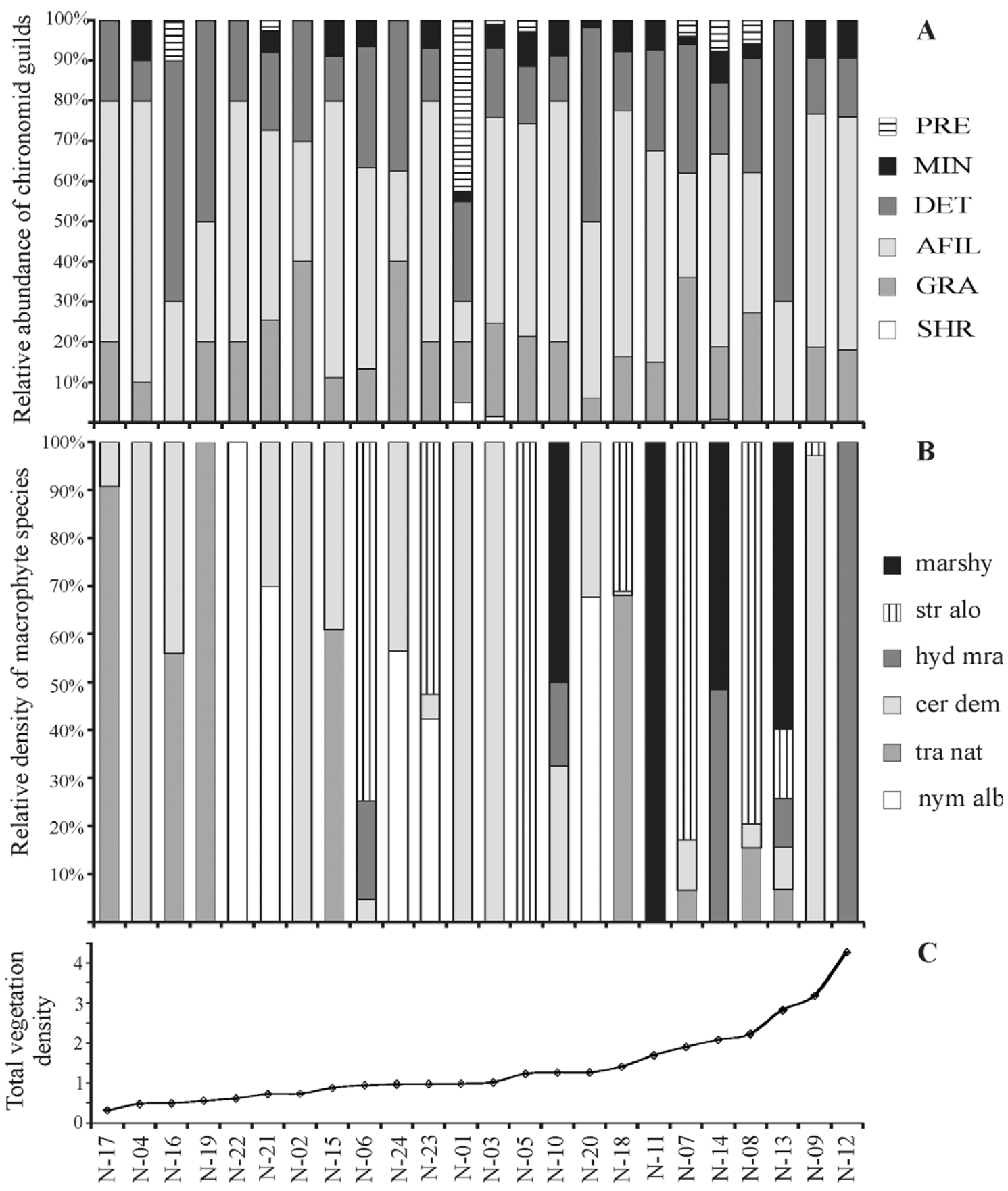

Fig. 3. Relative abundance of chironomid functional feeding guilds (A) and density of macrophyte species (B) in the Nagymorotva (NAGM) backwater, Hungary with the sites sample sorted along a gradient of increasing vegetation density $\left(\mathrm{kg} \mathrm{m}^{-3}\right)(\mathrm{C})$. List of the abbreviations of plant species is given in Table 1, while the abbreviations of functional feeding groups are SHR $=$ shredders, GRA = grazers, DET = detritus feeders, AFIL = active-filter feeders, MIN = miners and PRE = predators.

sitional" variables, the densities of $N$. alba, S. aloides and T. natans (Table 3). These three variables, together with total vegetation density and vegetation cover were associated mainly with the first axis. Vegetation stands dominated by floating-leaved $T$. natans and $N$. alba are located on the right side of the diagram and associated with Chironomus spp. and Cladopelma virescens that feed mainly on detritus. The second axis correlated mostly with Potamogeton spp., marshy vegetation and distance from the nearest area of open water, and the position of Prorcladius sp., Chironomus annularius agg. and Glyptotendipes viridis suggest a possible relationship with these variables. However, most of the chironomid taxa are positioned in the centre of the graph, suggesting that their occurrence was not significantly influenced by vegetation characteristics.

For NAGM, the CCA explained $55.6 \%$ of the total variation in the data, and the first two axes explained $39.3 \%$ of the relation in the species-environment data and $21.8 \%$ of the variance in species data, however, even the whole model was not significant (Fig. 5). Forward selection procedure indicated only one significant variable, the 
TABLE 2. List of chironomid taxa, their abbreviations and abundances (ind $\mathrm{m}^{-3}$ ) recorded in the Boroszló-kerti-Holt-Tisza (BKHT) and Nagy-morotva (NAGM) backwaters, Hungary. Between backwater differences in the examined variables were tested with paired t-test and statistical differences are indicated as follows: ${ }^{*} P<0.05,{ }^{* *} P<0.01$.

\begin{tabular}{|c|c|c|c|c|c|}
\hline \multirow{2}{*}{ Taxon } & \multirow{2}{*}{ Abbreviation } & \multicolumn{2}{|c|}{ BKHT } & \multicolumn{2}{|c|}{ NAGM } \\
\hline & & Mean (SD) & Range & Mean (SD) & Range \\
\hline Tanypus kraatzi (Kieffer, 1912) & Tpu kra & $0.38(1.31)$ & $0-5$ & $0.76(3.24)$ & $0-15.79$ \\
\hline Procladius sp. & Pro spe & $0.71(2.04)$ & $0-7.5$ & 0 & 0 \\
\hline Anatopynia plumipes (Fries, 1823) & Ana plu & 0 & 0 & $0.29(1.03)$ & $0-4.35$ \\
\hline Ablabesmyia longistyla Fittkau, 1962 & Abl lon & $0.37(1.32)$ & $0-5.71$ & 0 & 0 \\
\hline Ablabesmyia monilis (Linnaeus, 1758) & Abl mon & $0.19(0.96)$ & $0-4.82$ & 0 & 0 \\
\hline Ablabesmyia phatta (Egger, 1863) & Abl pha & $0.19(0.97)$ & $0-4.88$ & $0.18(0.89)$ & $0-4.35$ \\
\hline Cricotopus sylvestris gr. & Cri syl & $1.08(3.27)$ & $0-14.28$ & $0.62(1.69)$ & $0-5.31$ \\
\hline Chironomus (Camptochironomus) sp. & Chi spe & 0 & 0 & $1.22(3.10)$ & $0-12.5$ \\
\hline Chironomus annularius agg. & Chi ann & $0.89(2.48)$ & $0-10$ & $1.97(3.16)$ & $0-9.09$ \\
\hline Chironomus luridus gr. & Chi lur * & 0 & 0 & $4.05(7.54)$ & $0-31.58$ \\
\hline Chironomus nuditarsis Keyl, 1961 & Chi nut & $0.15(0.77)$ & $0-3.85$ & 0 & 0 \\
\hline Chironomus plumosus agg. & Chi plu & $1.26(3.06)$ & $0-12.12$ & $0.65(1.80)$ & $0-7.69$ \\
\hline Chironomus riparius agg. & Chi rip * & $1.95(3.39)$ & $0-12.19$ & 0 & 0 \\
\hline Chironomus dorsalis Meigen, 1818 & Chi dor ** & $0.13(0.67)$ & $0-3.33$ & $4.41(6.92)$ & $0-21.05$ \\
\hline Cladopelma virescens (Meigen, 1818) & Cla vir * & $2.23(3.76)$ & $0-14.81$ & 0 & 0 \\
\hline Dicrotendipes lobiger (Kieffer, 1921) & Dic lob & $0.1(0.5)$ & $0-2.5$ & $0.65(1.42)$ & $0-5.26$ \\
\hline Dicrotendipes nervosus (Staeger, 1839) & Dic ner $* *$ & $1.61(2.60)$ & $0-7.32$ & 0 & 0 \\
\hline Dicrotendipes tritomus (Kieffer, 1916) & Dic tri & $0.45(1.41)$ & $0-5.71$ & $0.14(0.48)$ & $0-1.83$ \\
\hline Endochironomus albipennis (Meigen, 1830) & Ech alb & 0 & 0 & $1.77(7.19)$ & $0-35.40$ \\
\hline Endochironomus tendens (Fabricius, 1775) & Ech ten & $4.46(8.88)$ & $0-40$ & $3.64(9.01)$ & $0-34.34$ \\
\hline Glyptotendipes viridis (Macquart, 1834) & Gly vir & $3.18(8.36)$ & $0-29.79$ & $0.36(1.15)$ & $0-5.26$ \\
\hline Glyptotendipes cauliginellus (Kieffer, 1913) & Gly cgi & $4.78(7.59)$ & $0-29.27$ & $6.49(11.39)$ & $0-36.84$ \\
\hline Glyptotendipes pallens (Meigen, 1804) & Gly pal & $9.05(20.16)$ & $0-80$ & $4.43(9.60)$ & $0-42.10$ \\
\hline Kiefferulus tendipediformis (Goetghebuer, 1921) & Kie ten $* *$ & $12.88(16.49)$ & $0-52.05$ & $0.36(1.26)$ & $0-5.26$ \\
\hline Parachironomus arcuatus gr. & Pch arc & $2.65(5.18)$ & $0-19.51$ & $0.67(1.38)$ & $0-4.08$ \\
\hline Phaenopsectra flavipes (Meigen, 1818) & Pha fla & $3.31(7.09)$ & $0-34.04$ & $1.89(4.95)$ & $0-21.92$ \\
\hline Polypedilum sordens (van der Wulp, 1874) & Pol sor & $27.21(61.56)$ & $0-275$ & $2.52(5.07)$ & $0-23$ \\
\hline Polypedilum nubeculosum (Meigen, 1804) & Pol nub * & $1.94(4.68)$ & $0-19.23$ & 0 & 0 \\
\hline Polypedilum cultellatum Goetghebuer, 1931 & Pol cul & $0.45(1.77)$ & $0-8.51$ & $0.73(1.65)$ & $0-5.48$ \\
\hline Synendotendipes dispar gr. & Syn dis & $1.20(2.66)$ & $0-11.11$ & $2.66(8.30)$ & $0-31.58$ \\
\hline Zavreliella marmorata (van der Wulp, 1858) & Zav mar & $0.11(0.55)$ & $0-2.74$ & 0 & 0 \\
\hline Micropsectra atrofasciata agg. & Mic atr & $0.11(0.55)$ & $0-2.74$ & 0 & 0 \\
\hline Paratanytarsus sp. & Pta spe * & $1.16(2.73)$ & $0-10.71$ & 0 & 0 \\
\hline Tanytarsus sp. & Tan spe & $2.15(5.73)$ & $0-19.17$ & 0 & 0 \\
\hline Total density of chironomids & & $86.35(105.38)$ & $2.38-407.14$ & $40.49(43.18)$ & $1.85-210.53$ \\
\hline Number of taxa & & 30 & & 22 & \\
\hline
\end{tabular}

depth of the water (Table 3), which correlated most with the density of the chironomid Endochironomus albipennis. The only other chironomid taxa positioned distantly from the centre of the graph is Chironomus plumosus agg., suggesting some relationship with $C$. demersum and T. natans densities, as well with the distance from an area of open water, vegetation cover and distance from the shore.

CCA ordinations did not reveal any significant relationships between vegetation attributes and functional feeding group based chironomid assemblages in either backwater (Table 3, Figs 4-5).

MRA revealed that the taxon richness of the chironomid assemblage is correlated positively with vegetation density and negatively with distance from an open area of water at BKHT, but it did not correlate with any vegetation attribute at NAGM (Table 4, Fig. 6). Total density of chironomids correlated positively with vegetation density and negatively with $N$. alba at BKHT. Again, no correlation was found in the data for NAGM (Table 4, Fig. 6). 
TABLE 3. Results of forward selection procedure of vegetation stand variables (abbreviations are given in Table 1) in the canonical correspondence analysis (CCA) exploring patterns in macrophyte associated chironomid assemblages in the Boroszló-kerti-Holt-Tisza (BKHT) and in Nagy-morotva (NAGM) backwaters, Hungary.

\begin{tabular}{|c|c|c|c|c|c|}
\hline Variable & $\begin{array}{l}\text { Cumulative } \\
\text { eigenvalues }\end{array}$ & $P$ & Variable & $\begin{array}{l}\text { Cumulative } \\
\text { eigenvalues }\end{array}$ & $P$ \\
\hline \multicolumn{6}{|c|}{ chironomid species $\times$ variables } \\
\hline \multicolumn{6}{|c|}{ BKHT } \\
\hline nym alb & 0.17 & 0.012 & cover & 0.02 & 0.188 \\
\hline str alo & 0.33 & 0.012 & cer dem & 0.03 & 0.276 \\
\hline marshy & 0.46 & 0.092 & disshore & 0.05 & 0.112 \\
\hline vegdens & 0.57 & 0.070 & disopen & 0.07 & 0.106 \\
\hline tra nat & 0.71 & 0.030 & tra nat & 0.08 & 0.296 \\
\hline cover & 0.83 & 0.064 & vegdens & 0.09 & 0.382 \\
\hline disshore & 0.95 & 0.056 & vegsize & 0.09 & 0.536 \\
\hline vegsize & 1.06 & 0.096 & marshy & 0.10 & 0.626 \\
\hline pot spe & 1.13 & 0.402 & str alo & 0.11 & 0.400 \\
\hline disopen & 1.23 & 0.078 & pot spe & 0.11 & 0.624 \\
\hline cer dem & 1.29 & 0.482 & nym alb & 0.11 & 0.870 \\
\hline \multicolumn{6}{|c|}{ NAGM } \\
\hline depth & 0.21 & 0.020 & tra nat & 0.02 & 0.162 \\
\hline tra nat & 0.39 & 0.078 & depth & 0.03 & 0.278 \\
\hline str alo & 0.56 & 0.072 & cover & 0.04 & 0.400 \\
\hline disopen & 0.73 & 0.084 & disshore & 0.05 & 0.480 \\
\hline hyd mra & 0.85 & 0.322 & disopen & 0.05 & 0.472 \\
\hline cer dem & 0.96 & 0.364 & nym alb & 0.07 & 0.268 \\
\hline nym alb & 1.07 & 0.398 & vegsize & 0.08 & 0.346 \\
\hline vegsize & 1.15 & 0.688 & vegdens & 0.08 & 0.578 \\
\hline cover & 1.25 & 0.478 & marshy & 0.09 & 0.354 \\
\hline vegdens & 1.33 & 0.648 & str alo & 0.10 & 0.488 \\
\hline disshore & 1.43 & 0.562 & hyd mra & 0.11 & 0.676 \\
\hline marshy & 1.52 & 0.554 & cer dem & 0.11 & 0.910 \\
\hline
\end{tabular}

Taxonomic and functional level influence of vegetation on chironomids

Out of the nine most abundant chironomid taxa, seven showed some correlation with vegetation attributes at BKHT. The relative contribution of pure "structural" (18-38\%) and pure "compositional" variables (12-53\%) to multiple linear regression models depended on the chironomid taxa, and the explanatory power of overall regression models (i.e. including affects of pure "compositional" and pure "structural" variables as well their shared effect) ranged between 10-28\%, while a larger part of the variance $(38-77 \%)$ in the data for BKHT remained unexplained. In contrast, only "structural" variables in the significant multiple regression models for the three guilds had significant explanatory power (23-32\%) (Table 4, Fig. 6). In the NAGM data only a significant vegetation effect was for $G$. cauliginellus and G. pallens, and the guild of predators (Table 4, Fig. 6).

In general, the results of the MRA indicated that pure "compositional" variables had only a minor influence $\left(R_{a d j .}^{2} \leq 0.3\right)$ on densities of chironomid taxa and functional groups, except for the $C$. riparius agg. $\left(R_{a d j .}^{2}=\right.$
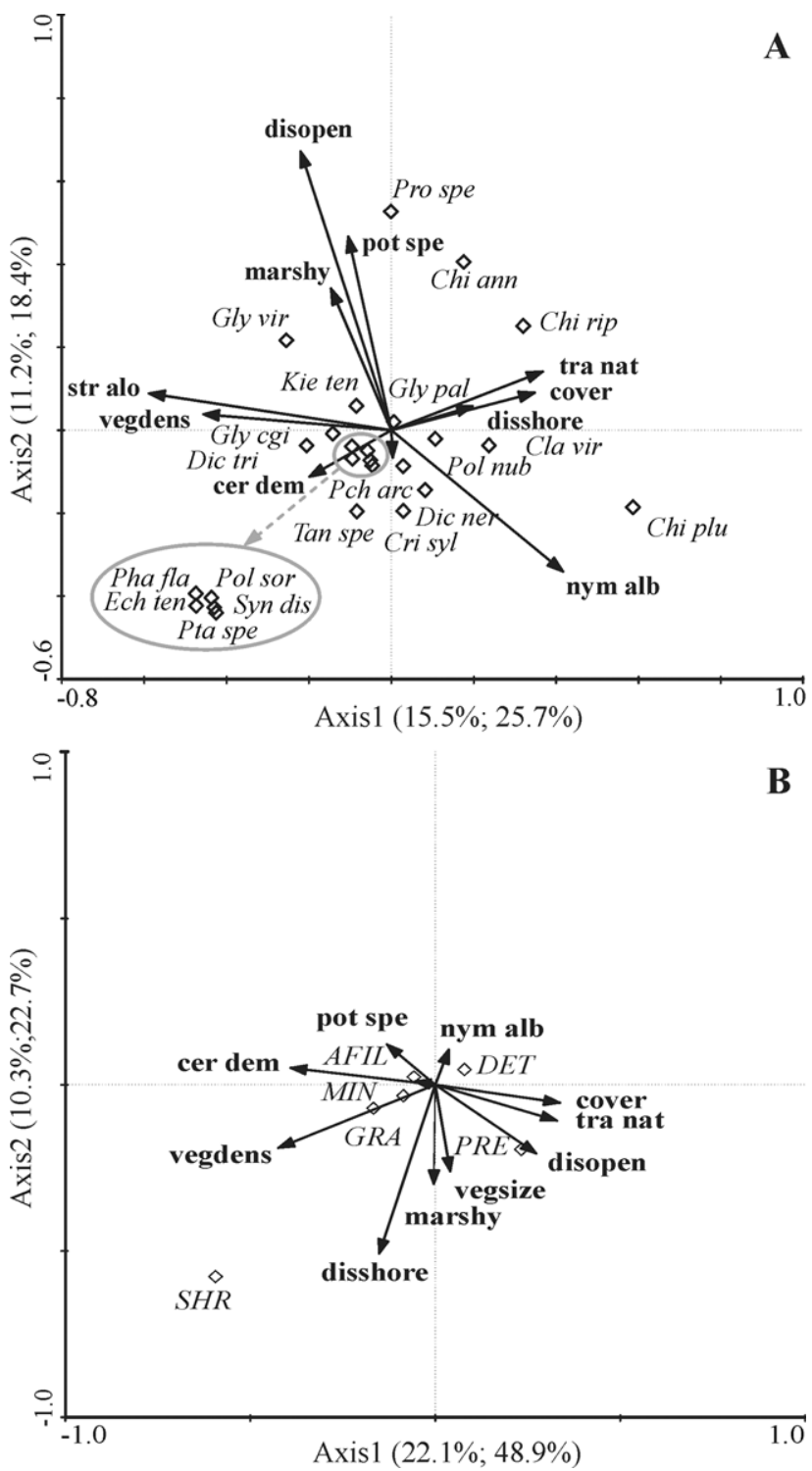

Fig. 4. Canonical correspondence analysis (CCA) plots depicting the relationships between vegetation stand attributes and chironomid assemblages in Boroszló-kerti-Holt-Tisza (BKHT) based on chironomid taxa (A) and functional feeding groups (B). Percentage variances represented by axes are indicated in brackets (of species data; of species-vegetation relation) after the axis name. Lists of abbreviations of environmental variables and chironomid taxa are given in Table $1-2$, while abbreviations of functional feeding groups are $\mathrm{SHR}=$ shredders, GRA $=$ grazers, DET $=$ detritus feeders, $\mathrm{AFIL}=$ active-filter feeders, $\mathrm{MIN}=$ miners and PRE $=$ predators. Note that, only the CCA shown in plot A is significant $(F=1.82, P=0.004)$, and none of the individual axes have statistically significant explanatory power; for clarity some variables close to the centre of the graph do not have a legend.

$0.534, P<0.001)$ at BKHT and $G$. pallens $\left(R_{a d j .}^{2}=0.372\right.$, $P<0.003)$ at NAGM. Although, pure "structural" variables had a greater influence on chironomids their significant contribution was also limited to certain chironomid taxa/guilds and restricted mainly to BKHT (Table 4, Fig. 6). Shared effect of "structural" and "compositional" variables proved to be significant for E. tendens $\left(R_{a d j .}^{2}=\right.$ 

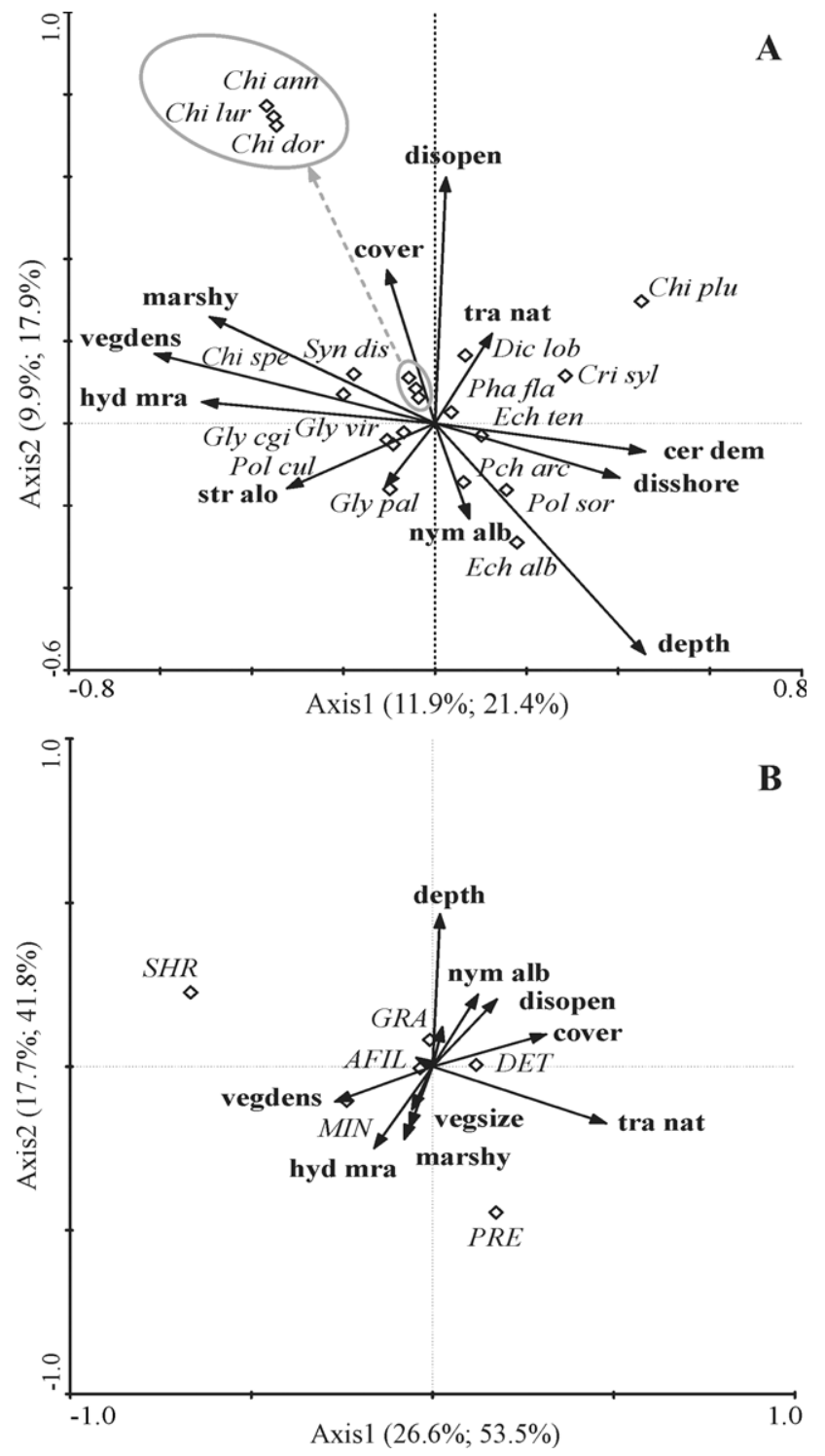

Fig. 5. Canonical correspondence analysis (CCA) plots depicting the relationships between vegetation stand attributes and chironomid assemblages in Nagy-morotva (NAGM) based on chironomid taxa (A) and functional feeding groups (B). Percentage variances represented by axes are indicated in brackets (of species data; of species-vegetation relation) after the axis name. Lists of abbreviations of environmental variables and chironomid taxa are given in Table $1-2$, while abbreviations of functional feeding groups are SHR $=$ shredders, GRA $=$ grazers, DET $=$ detritus feeders, AFIL $=$ active-filter feeders, MIN = miners and PRE $=$ predators. Note that in the CCA shown in plot B one outlying site is not included (explained in the text); for clarity some variables very close to the centre of the graph do not have a legend.

0.453, $P<0.001)$, G. cauliginellus $\left(R_{\text {adj. }}^{2}=0.429, P<\right.$ $0.005), K$. tendipediformis $\left(R_{\text {adj. }}^{2}=0.622, P<0.001\right)$ and $P$. sordens $\left(R_{a d j .}^{2}=0.464, P<0.001\right)$ at BKHT, and $G$. cauliginellus $\left(R^{2}{ }_{a d j .}=0.358, P<0.005\right)$ at NAGM (Fig. 6).

Of the "compositional" variables mainly densities of floating leaved macrophyte species had significant explanatory values for the density of chironomid taxa, except
C. riparius agg., which correlated with both the densities of Potamogeton spp. and C. demersum. S. aloides correlated positively with $E$. tendes $(B=0.47, P<0.05), G$. cauliginellus $(\beta=0.53, P<0.01)$, and $P$. flavipes $(\beta=$ $0.35, P=0.07)$, and negatively with $C$. riparius agg. $(B=$ $-0.51, P<0.01)$ in BKHT, while $N$. alba correlated negatively with $C$. riparius agg. $(\beta=-0.66, P<0.01)$, K. tendipediformis $(\beta=-0.41, P<0.01)$ and $P$. sordens $(\beta=$ $-0.39, P<0.05)$ at BKHT. T natans correlated negatively with $K$. tendipediformis $(\beta=-0.37, P<0.05)$ at BKHT and with $G$. pallens $(\beta=-0.35, P<0.05)$ at NAGM; while, H. morsus-ranae correlated positively with $G$. cauliginellus $(\beta=0.48, P<0.05)$ and $G$. pallens $(\beta=0.5, P<$ $0.01)$ at NAGM (Table 4).

Of the "structural" variables total vegetation density correlated positively with the density of $E$. tendes $(B=$ $0.41, P<0.05), G$. cauliginellus $(\beta=0.56, P<0.01), G$. pallens $(\beta=0.71, P<0.001), K$. tendipediformis $(\beta=$ $0.51, P<0.01)$ and $P$. sordens $(\beta=0.66, P<0.01)$ at BKHT, and the density of $G$. cauliginellus $(\beta=0.60, P<$ $0.002)$ at NAGM. The density of $G$. pallens and $P$. sordens both correlated negatively $(\beta=-0.36, P<0.05 ; \beta=$ $-0.50, P<0.01$, respectively) with the distance from open water at BKHT, while the distance from the lakeshore correlated negatively with that of $K$. tendipediformis $(B=$ $-0.55, P<0.01)$ at BKHT and positively with predator guild $(\beta=0.62, P<0.01)$ at NAGM. Miners $(\beta=-0.51$, $P<0.01)$, in particular $E$. tendes $(\beta=-0.53, P<0.01)$, correlated negatively with vegetation cover at BKHT (Table 4).

\section{DISCUSSION}

It is well-known that the compositions of macroinvertebrate communities living on macrophytes differ from those living in other habitats, like sediment or decomposing organic matter; and a similar pattern is recorded for the composition of chironomid assemblages (e.g. Soszka, 1975a; Pinder, 1986). In addition, macroinvertebrate assemblages vary among macrophyte beds mainly in relation to the heterogeneity of the environment, plant architecture, plant species composition and vegetation density (reviewed by Papas, 2007). Therefore, it is logical to assume that (1) particular chironomid assemblages are associated with particular types of vegetation, (2) vegetation pattern should be more important in shaping the distribution of chironomids living in this habitat than those associated with other substrates (i.e. benthic species), and (3) that the relationships between chironomid assemblages and the vegetation may be more obvious in terms of functional groups than species of chironomids (e.g. Erős et al., 2009 and references cited therein). In contrast, in this study, there was no relationship between the spatial distributions of chironomid species or functional feeding groups and characteristics of macrophyte stands over wide structural and compositional gradients. Moreover plant-dwelling chironomids seemed to be highly opportunistic in terms of the plant taxa they were associated with in the aquatic systems studied. 
TABLE 4. Multiple linear regression models of the relationships between chironomid species richness, total abundance of chironomids, and abundance of dominant taxa and functional feeding groups (GRA $=$ grazers, AFIL $=$ active filter-feeders, DET $=$ detritus feeders, $\mathrm{MIN}=$ miners, $\mathrm{PRE}=$ predators), and the attributes of the vegetation in the Boroszló-kerti-Holt-Tisza (BKHT) and Nagy-morotva (NAGM) backwaters, Hungary. Explanatory variables in the structural and compositional submodels were selected using the forward stepwise method (at $P<0.05$ ) and only significant variables were included in the overall model (" + " indicates positive, "-" negative and "ns" non significant relationship). For lists of abbreviations see Tables 1-2.

\begin{tabular}{|c|c|c|c|c|c|}
\hline & \multirow{2}{*}{ Compositional submodel } & \multirow{2}{*}{ Structural submodel } & \multicolumn{3}{|c|}{ Overall model } \\
\hline & & & df & $F$ & $P$ \\
\hline \multicolumn{6}{|l|}{ BKHT } \\
\hline taxon richness & +vegdens; -disopen & ns & 2,22 & 6.79 & $<0.005$ \\
\hline total density & +vegdens & -nym alb & 2,22 & 9.06 & $<0.001$ \\
\hline Chi rip & ns & $\begin{array}{c}\text { +pot spe; }- \text { str alo; }- \text { nym } \\
\text { alb; - cer dem }\end{array}$ & 4,20 & 7.89 & $<0.001$ \\
\hline Cla vir & $\mathrm{ns}$ & ns & - & - & $\mathrm{ns}$ \\
\hline Ech ten & -cover; + vegdens & + str alo & 3,21 & 7.62 & $<0.001$ \\
\hline Gly cgi & +vegdens & + str alo & 2,22 & 10.04 & $<0.001$ \\
\hline Gly pal & +vegdens; -disopen & $\mathrm{ns}$ & 2,22 & 8.23 & $<0.002$ \\
\hline Kie ten & -disshore; +vegdens & -nym alb; -tra nat & 4,20 & 10.86 & $<0.001$ \\
\hline Pch arc & ns & ns & - & - & $\mathrm{ns}$ \\
\hline Pha fla & ns & + str alo & 3,21 & 3.46 & $<0.034$ \\
\hline Pol sor & +vegdens; -disopen & - nym alb & 3,21 & 7.92 & $<0.001$ \\
\hline GRA & -disopen; +vegdens & ns & 2,22 & 6.60 & $<0.005$ \\
\hline AFIL & $\mathrm{ns}$ & $\mathrm{ns}$ & - & - & ns \\
\hline DET & -vegdens & $\mathrm{ns}$ & 1,23 & 8.93 & $<0.006$ \\
\hline MIN & -cover & $\mathrm{ns}$ & 1,23 & 8.28 & $<0.008$ \\
\hline PRE & ns & ns & - & - & ns \\
\hline \multicolumn{6}{|l|}{ NAGM } \\
\hline taxon richness & ns & ns & - & - & ns \\
\hline total density & ns & $\mathrm{ns}$ & - & - & $\mathrm{ns}$ \\
\hline Chi lur & ns & ns & - & - & ns \\
\hline Chi dor & ns & $\mathrm{ns}$ & - & - & ns \\
\hline Ech alb & ns & $\mathrm{ns}$ & - & - & ns \\
\hline Ech ten & $\mathrm{ns}$ & $\mathrm{ns}$ & - & - & $\mathrm{ns}$ \\
\hline Gly cgi & +vegdens & +hyd mra & 2,21 & 7.43 & $<0.004$ \\
\hline Gly pal & ns & +hyd mra; -tra nat & 2,21 & 7.81 & $<0.003$ \\
\hline Pha fla & ns & ns & - & - & ns \\
\hline Pol sor & ns & $\mathrm{ns}$ & - & - & $\mathrm{ns}$ \\
\hline GRA & $\mathrm{ns}$ & $\mathrm{ns}$ & - & - & $\mathrm{ns}$ \\
\hline AFIL & ns & ns & - & - & $\mathrm{ns}$ \\
\hline DET & ns & ns & - & - & ns \\
\hline MIN & $\mathrm{ns}$ & ns & - & - & ns \\
\hline PRE & + disshore; -depth & ns & 2,21 & 8.35 & $<0.002$ \\
\hline
\end{tabular}

Similar chironomid assemblages did not unequivocally relate to similar vegetation compositions in the two backwaters. Moreover, the taxonomic diversity of chironomid assemblages did not correlate with the diversity of macrophyte stands in the investigated habitats. This is surprising because of the great variety in the morphology and taxonomic composition of the macrophyte taxa occurring at BKHT and NAGM, and several other authors (e.g. Ali et al., 2007; Papas, 2007; Tessier et al., 2008) record a positive correlation between the diversity of macro-invertebrate communities and heterogeneity of aquatic macro-vegetation. Similarly, there are positive correlations recorded between plant and arthropod species compositions in terrestrial environments (e.g. Schaffers et al., 2008). In our study, the CCAs indicated that taxonomic composition and structural characteristics of the vegetation had little influence on the taxonomic or functional (i.e. feeding groups) composition of the chironomid assemblages inhabiting them.

Similarly, CCAs did not reveal any significant relationships just some weak trends between the distribution of certain chironomid species and functional feeding groups, and environmental variables. For instance, at BKHT detritivore midge taxa (e.g. C. annularius agg., $C$. riparius agg., C. plumosus agg., C. virescens) were associated mainly with macrophytes with floating leaves (Trapa natans and Nymphaea alba) and with relatively high vegetation cover (77-78\%), while the miner chiro- 


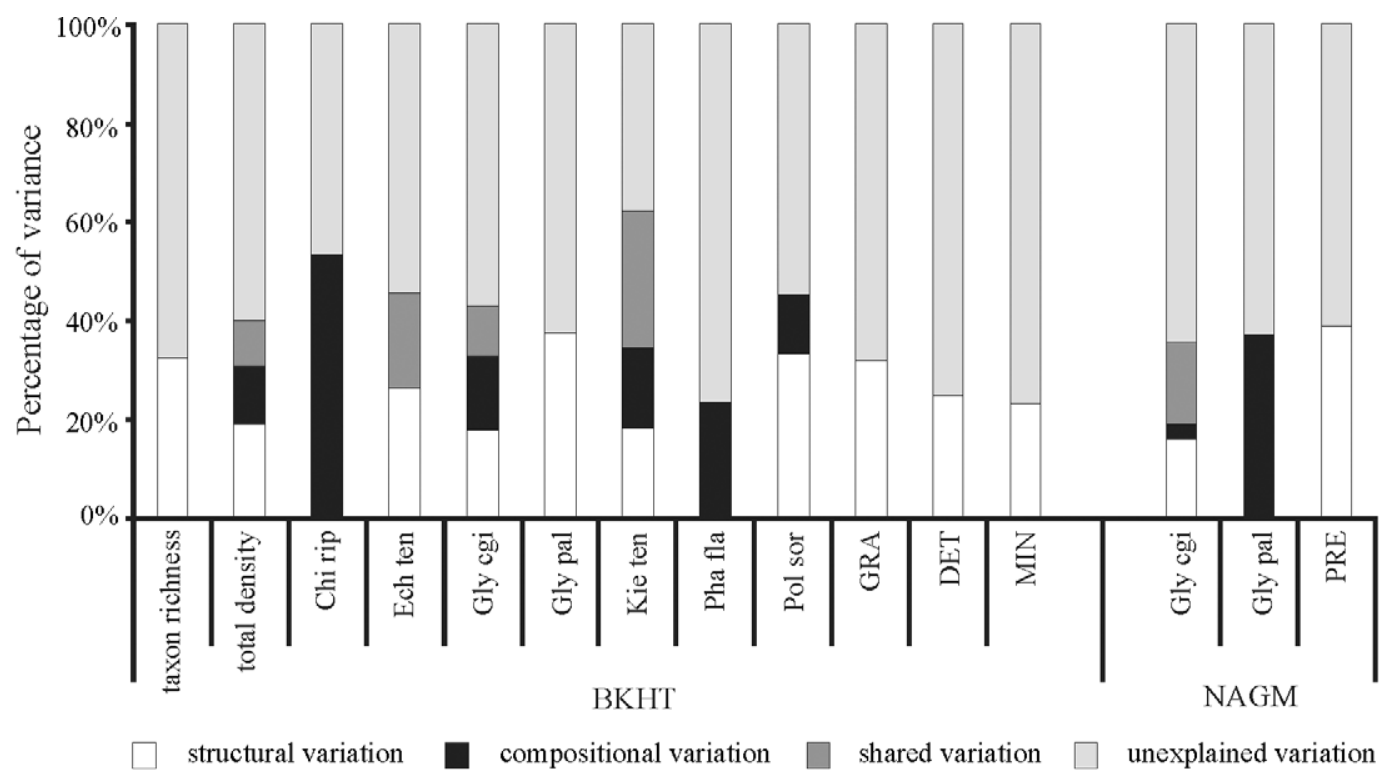

Fig. 6. Percentage of the variation of various aspects of the chironomid assemblages studied accounted for by "structural" and "compositional" components of the macrophyte vegetation in the Boroszló-kerti-Holt-Tisza (BKHT) and Nagy-morotva (NAGM) backwaters, Hungary. Only variables having a significant contribution in pure "structural" and "compositional" multiple linear regression models were included in the overall model. Variables included in specific models are presented in Table 4. List of the abbreviations for chironomid taxa is given in Table 2, while abbreviations of functional feeding groups are: GRA = grazers, DET = detritus feeders, $\mathrm{MIN}=$ miners and $\mathrm{PRE}=$ predators.

nomid, G. viridis, was associated primarily with marshy vegetation. At NAGM there was a weak positive relationship between the distribution of E. albipennis and the depth of the water, as previously reported (Moller Pillot, 2009).

More specific analyses based on MRA and aiming to explore relationships between chironomids and the attributes of stands of vegetation also did not reveal any strong relationships. In general, some significant relationships were found in the BKHT data, but these trends were not found in the NAGM data. Taxon richness of chironomids correlated positively with vegetation density and negatively with distance from the nearest area of open water in the BKHT data, but did not correlate with any of the variables in the NAGM data. The latter result accords with the findings of Balci \& Kennedy (2003) who also did not find differences in the taxon richness of chironomids in various types of vegetation. It is even more interesting that the total density of chironomids was not unequivocally associated with any parameter in any of the stands of vegetation investigated. Although it correlated positively with vegetation density and negatively with the density of $N$. alba at BKHT, however it was not correlated with any of the parameters at NAGM. In addition the literature on this topic is contradictory. Cremona et al. (2008) records greater abundances and biomasses of macro-invertebrates on submerged than on emergent and floating leaved macrophytes, which accords with some other studies (e.g., Dvorak \& Best, 1982; Cattaneo et al., 1998), however there are a number of contrary observations (e.g., Soszka et al., 1975a, b; Cyr \& Downing, 1988; Pieczynska et al., 1999; Bogut et al., 2007).
In general, the explanatory power of the "structural" variables of vegetation as determinants of the distribution of dominant chironomid taxa was greater than that of "compositional" variables. However, the results are contradictory as Glyptotendipes cauliginellus was the only chironomid whose distribution followed similar trends in the two backwaters. Its density correlated positively with vegetation density at both backwaters and positively with the density of the floating leaved $S$. aloides at BKHT and H. morsus-ranae at NAGM. It should be noted, however, that $H$. morsus-ranae occurred only at NAGM and in association with $S$. aloides and marshy vegetation. Therefore, H. morsus-ranae may indicate the features of the vegetation stands it dominates rather than it being an important living place for G. cauliginellus. This is supported by the report that the larvae of miners like G. cauliginellus primarily mine the old tissues of leaves and stems of $S$. aloides and emergent marshy macrophytes (e.g. Typha, Sparganium, Phragmites and Glyceria species) (Koperski, 1998; Tarkowska-Kukuryk, 2006; Moller Pillot, 2009).

Like the present findings there are reports of strong relationships between the abundance and distribution of herbivorous insects and the structural complexity, density and spatial pattern (patch size and isolation) of the vegetation in terrestrial environments (e.g. Langelotto \& Denno, 2004; Crist et al., 2006; Obermaier et al., 2008; Randlkofer et al., 2009). In terrestrial systems density, height and fragmentation of the vegetation seem to be the most important at the habitat level and at the individual plant level it is mainly plant height that has a strong positive influence on herbivore distribution and oviposition (Crist et al., 2006; Obermaier et al., 2008; Randlkofer et 
al., 2009). However, in other cases plant species composition and structural features of the vegetation have an important influence on the community structure of insects (e.g. Crist et al., 2006; Schaffers et al., 2008). For example, Schaffers et al. (2008) compare the species composition of seven functional groups of arthropods with plant species composition, vegetation structure, flower richness, landscape composition and environmental data and demonstrate a stronger relation between the species composition of arthropod and plant communities than with vegetation structure and environmental conditions.

In our study, as in some previous studies (e.g. Dvorak \& Best, 1982; Cattaneo et al., 1998; Strayer et al., 2003), the distribution of chironomids was most closely associated with total density of macrophytes. Vegetation cover and distance from the nearest area of open water, as well the presence of floating leaved macrophytes (such as Trapa natans and Nymphaea alba) negatively influenced the abundance of some chironomids (e.g. C. riparius agg., E. tendens, K. tendipediformis, P. sordens, G. pallens). Similar observations are reported by Marklund et al. (2001), who investigated the distribution and diel migration of macro-invertebrates in dense beds of Chara. They found that total abundance of macro-invertebrates is higher at the edge of macrophyte stands than in the innermost parts, even during daytime and in spite of predation pressure. Similarly, several authors suggest that too dense a stand of macrophytes with a high percentage vegetation cover could alter the physico-chemical features of the underlying environment and make it unfavourable for invertebrates (e.g. Cheruvelil et al., 2002; Papas, 2007). Moreover, certain plant species (e.g. Ceratophyllum demersum, Myriophyllum spicatum, Chara spp.) secrete antialgal-compounds, which limit the growth of epiphytic algae (Ervin \& Wetzel, 2003). Since the epiphyton is a very important food source for aquatic macroinvertebrates (e.g. Cattaneo et al., 1998; Balci \& Kennedy, 2003; Papas, 2007; Bogut et al., 2010) these chemicals could also indirectly influence the distribution and density of macro-invertebrates (like chironomids).

Chironomids differ from each other in their feeding habits and although it is difficult to classify some of the species into well defined guilds since the guild to which they are assigned depends on the life stage and what food resource is available (Armitage et al., 1995; Moog, 2002). In this study six functional feeding groups were identified of which active filter-feeders, detritus feeders and grazers were the most abundant, while shredders, miners and predators occurred in smaller numbers. However, their distribution was not influenced either by the structure or taxonomic composition of the vegetation. In contrast, Cremona et al. (2008) report a clear relationship between the architecture of the vegetation and the density of various macro-invertebrate guilds. These authors suggest that detritivores and predators prefer macrophytes with a complex structure, while grazers choose chiefly simple structured vegetation. The most likely explanation of the latter observation is that simple structured macrophytes allow more light to penetrate thus favouring the growth of periphyton and so provide more food for grazers (Cremona et al., 2008; Tessier et al., 2008). However, the taxonomic resolution used in the above paper is low (i.e. chironomids were only classified to subfamily level), which might bias the results.

Present analyses identified only weak relationships between the aquatic vegetation and their chironomid fauna, however, the high level of inconsistencies in the results suggest that even these relationships should be viewed with caution and further analyses are needed to establish their validity. The most obvious discrepancy is that majority of the significant relationships were only for BKHT, with the exception of the chironomid Glyptotendipes cauliginellus (discussed above). Different characteristics of the two backwaters may explain most of the above differences in their macrophyte-chironomid relationships (Ali et al., 2002). Namely, BKHT was established relatively recently and is at an early stage of succession while NAGM is at a later stage of succession, the transition between pond and marsh. The macrophyte stands at NAGM were considerately larger and denser than those at BKHT, which indicates that dense vegetation may negatively influence algal production, oxygen concentration at night and as a consequence the density and productivity of macro-invertebrates (Cheruvelil et al., 2002; Papas, 2007; Cremona et al., 2008) (see above). In some parts of NAGM the density of macro-vegetation was probably above this critical level. Therefore, it is likely that the relationship between chironomids and macrophytes is not linear over the entire vegetation density scale, but hump-shaped when high vegetation densities are included. This assumption is supported by the lower abundance (around half compared to BKHT) of chironomids at NAGM.

In several earlier publications other factors than habitat type and plant morphology or architecture are said to significantly affect the composition of macro-invertebrate communities and the distribution of certain invertebrates (Papas, 2007). The factors cited are the trophic state of a lake (Pieczynska et al., 1999; Bogut et al., 2007, 2010), depth of the water (Ali et al., 2002; Bogut et al., 2007, 2010; Engels \& Cwynar, 2011), nutrient content (Bogut et al., 2010), availability of epiphytic food (Marklund et al., 2001; Ali et al., 2002; Balci \& Kennedy, 2003; Cremona et al., 2008; Bogut et al., 2010; Hansen et al., 2010) and water chemistry (Cattaneo et al., 1998). Since some species of chironomid develop very rapidly and their development time may vary among habitats (e.g. Armitage et al., 1995; van den Berg et al., 1997; Tarkowska-Kukuryk, 2006) seasonality may also influence the trends in chironomid assemblages observed along habitat gradients, even if all samples are collected from all the sites within a short period of time. However, in the present study there is no evidence of the life cycle of any chironomid differing in the two backwaters.

In conclusion, present results demonstrate that macrophyte-chironomid associations are organized in a complex way as there is no simple relationship between the structure of chironomid assemblages and the taxo- 
nomic composition of the vegetation with which they are associated. It is suggested that the structure (i.e. position, stand size, total density) of aquatic vegetation and the characteristics of the environment where it develops may be more important in shaping plant-dwelling chironomid assemblages than the taxonomic composition of the vegetation.

ACKNOWLEDGEMENTS. We would like to express our thanks those who helped with the sampling and anonymous reviewers for helpful comments, which improved the quality of this paper. This research was supported by the OTKA Research Fund (F029825).

\section{REFERENCES}

Ali A., Frouz J. \& Lobinske R.J. 2002: Spatio-temporal effects of selected physico-chemical variables of water, algae and sediment chemistry on the larval community of nuisance Chironomidae (Diptera) in a natural and a man-made lake in central Florida. Hydrobiologia 470: 181-193.

Ali M.M., Mageed A.A. \& Heikal M. 2007: Importance of aquatic macrophyte for invertebrate diversity in large subtropical reservoir. Limnologica 37: 155-169.

Armitage P., Cranston P.S. \& Pinder L.C.V. (eds) 1995: The Chironomidae. The Biology and Ecology of Non-biting Midges. Chapman \& Hall, London, xii +572 pp.

Balci P. \& Kennedy J.H. 2003: Comparison of chironomids and other macroinvertebrates associated with Myriophyllum spicatum and Heteranthera dubia. J. Freshwater Ecol. 18: 235-247.

Bíró K. 1981: [A Guide for the Identification of Chironomid Larvae in Hungary. In Felföldy L. (ed.): Hydrobiology for Water Management Praxis, Vol. 11.] VÍZDOK, Budapest, 229 pp. [in Hungarian].

Bogut I., Vidaković J., Palijan G. \& Čerba D. 2007: Benthic macroinvertebrates associated with four species of macrophytes. Biologia 62: 600-606.

Bogut I., ČERba D., Vidaković J. \& Gvozdić V. 2010: Interactions of weed-bed invertebrates and Ceratophyllum demersum stands in a floodplain lake. Biologia 65: 113-121.

Borcard D., Legendre P., Avois-JacQuet C. \& Tuomisto H. 2004: Dissecting the spatial structure of ecological data at multiple scales. Ecology 85: 1826-1832.

Brodersen K.P., OdgaArd B.V., Vestergatrd O. \& Anderson J. 2001: Chironomid stratigraphy in the shallow and eutrophic Lake Søbygaard, Denmark: chironomid-macrophyte cooccurrence. Freshwat. Biol. 46: 253-267.

Cattaneo A., Galanti G., Gentinetta S. \& Romo S. 1998: Epiphytic algae and macroinvertebrates on submerged and floating-leaved macrophytes in an Italian lake. Freshwat. Biol. 39: 725-740.

Cheruvelil K.S., Soranno P.A., Madsen J.D. \& Roberson M.J. 2002: Plant architecture and epiphytic macroinvertebrate communities: the role of an exotic dissected macrophyte. $J$. $N$. Am. Benthol. Soc. 21: 261-277.

Cranston P.S. 1982: A key to the Larvae of the British Orthocladiinae (Chironominae). Freshwater Biological Association, Scientific Publication 45, 153 pp.

Cremona F., Panas D. \& Lucotte M. 2008: Biomass and composition of macroinvertebrate communities associated with different types of macrophyte architectures and habitats in a large fluvial lake. Arch. Hydrobiol. Fundam. Appl. Limnol. 171: 119-130.

Crist T.O., Pradhan-Devare S.V. \& Summerville K.S. 2006: Spatial distribution in insect community and species responses to habitat loss and plant community composition. Oecologia 147: 510-521.

CYR H. \& Downing J.A. 1988: The abundance of phytophilous invertebrates on different species of submerged macrophytes. Freshwat. Biol. 20: 365-374.

DraKe C.M. 1983: Spatial distribution of chironomid larvae (Diptera) on leaves of the bulrush in a chalk stream. J. Anim. Ecol. 52: 421-437.

DVORAK J. 1996: An example of relationships between macrophytes, macroinvertebrates and their food resources in a shallow eutrophic lake. Hydrobiologia 339: 27-36.

Dvorak J. \& BeST E.P.H. 1982: Macro-invertebrate communities associated with the macrophytes of Lake Vechten: structural and functional relationships. Hydrobiologia 95: $115-126$.

Engels S. \& CWynar L.C. 2011: Changes in fossil chironomid remains along a depth gradient: evidence for common faunal thresholds within lakes. Hydrobiologia 665: 15-38.

Erös T., Heino J., Schmera D. \& Rask M. 2009: Characterising functional trait diversity and trait-environment relationships in fish assemblages of boreal lakes. Freshwat. Biol. 54: 1788-1803.

Ervin G.N. \& Wetzel R.G. 2003: An ecological perspective of allelochemical interference in land-water interface communities. Plant Soil 256: 13-28.

Hammer Ø., Harper D.A.T. \& Ryan P.D. 2001: PAST: Paleontological statistics software package for education and data analysis. Palaeontol. Electron. 4(1): 9 pp.

Hansen J.P., Wikström S.A., Axemar H. \& Kautsky L. 2010: Distribution differences and active habitat choices of invertebrates between macrophytes of different morphological complexity. Aquat. Ecol. 45: 11-22.

HARROD J.J. 1964: The distribution of invertebrates on submerged aquatic plants in a chalk stream. J. Anim. Ecol. 33: 335-348.

JANECEK B.F.R. 1998: Diptera: Chironomidae (Zuckmücken). Bestimmung von 4. Larvenstadien mitteleuropäischer Gattungen und österreichischer Arten. In Moog O. (ed.): Fauna Aquatica Austriaca $V$. Universität für Bodenkultur, Wien, 117 pp.

Kondo S. \& Hamashima S. 1992: Habitat preferences of four chironomid species associated with aquatic macrophytes in an irrigation reservoir. Aquat. Ecol. 26: 371-377.

KOPERSKI P. 1998: Predator-prey interactions between larval damselflies and mining larvae of Glyptotendipes gripekoveni (Chironomidae): reduction in feeding activity as an induced defence. Freshwat. Biol. 39: 317-324.

KRECKER F.H. 1939: A comparative study of the animal population of certain submerged aquatic plants. Ecology 20: 553-562.

Langdon P.G., Ruiz Z., Wynne S., SAYer C.D. \& Davidson T.A. 2010: Ecological influences on larval chironomid communities in shallow lakes: implications for palaeolimnological interpretations. Freshwat. Biol. 55: 531-545.

Langelotto G.A. \& Denno R.F. 2004: Responses of invertebrate natural enemies to complex-structured habitats: a metaanalytical synthesis. Oecologia 139: 1-10.

LÁsZlófFY W. 1982. [The Tisza River. Waterworks and water Management in the Tisza Drainage System.] Akadémia Kiadó, Budapest, 610 pp. [in Hungarian].

LEGENDRE P. 2008: Studying beta diversity: ecological variation partitioning by multiple regression and canonical analysis. $J$. Plant Ecol. 1: 3-8.

Marklund O., Blindow I. \& Hargeby A. 2001: Distribution and diel migration of macroinvertebrates within dense submerged vegetation. Freshwat. Biol. 46: 913-924. 
Moller Pillot H.K.M. 2009: Chironomid Larvae. Biology and Ecology of the Chironomini. KNNV, Zeist, $270 \mathrm{pp}$.

Moog O. (ed.) 2002: Fauna Aquatica Austriaca. Wasserwirtschaftskataster, Bundesministerium für Land- und Forstwirtschaft, Umwelt und Wasserwirtschaft, Vienna

Nagy S., Dévai Gy., Delaune R.D., Dévai I., Kiss B. \& GrigORSZKY I. 2001: Aqualex: sampling device for quantitative collection of macroscopic organisms in densely vegetated emergent and/or submerged aquatic environments. Studia Odonatol. Hung. 7: 5-11.

Obermaier E., Heisswolf A., Poethike H.J., Randlkofer B. \& MeINERS T. 2008: Plant architecture and vegetation structure: Two ways for insect herbivores to escape parasitism. Eur. J. Entomol. 105: 233-240.

PAPAS P. 2007: Effect of Macrophytes on Aquatic Invertebrates - a Literature Review. Arthur Rylah Institute for Environmental Research, Technical Report Series No. 158, Melbourne Water, Melbourne, ii + 22 pp.

Pieczynska E., Kolodziejczyk A. \& Rybak J.I. 1999: The responses of littoral invertebrates to eutrophication-linked changes in plant communities. Hydrobiologia 391: 9-21.

PINDER L.C.V. 1986: Biology of freshwater Chironomidae. Annu. Rev. Entomol. 31: 1-23.

Randlkofer B., Jordan F., Mitesser O., Meiners T. \& OberMAIER E. 2009: Effect of vegetation density, height, and connectivity on the oviposition pattern of the leaf beetle Galeruca tanaceti. Entomol. Exp. Appl. 132: 134-146.

SÆther O.A. \& Spies M. 2004: Fauna Europaea: Chironomidae. In Jong H., de (ed.): Fauna Europaea: Diptera, Nematocera. Fauna Europaea version 1.5, http:// www.faunaeur.org (accessed 27 April 2010).

SÆther O.A., Ashe P. \& Murray D.A. 2000: A.6. Family Chironomidae. In Papp L. \& Darvas B. (eds): Contribution to a Manual of Palaearctic Diptera. Appendix. Science Herald, Budapest, pp. 113-334.

Schaffers A., Raemakers I.P., Sykora K.V. \& ter Braak C.J.F. 2008: Arthropod assemblages are best predicted by plant species composition. Ecology 89: 782-794.

Scheffer M., Achterberg A.A. \& Beltman B. 1984: Distribution of macro-invertebrates in a ditch in relation to the vegetation. Freshwat. Biol. 14: 367-370.

SoszKa G.J. 1975a: The invertebrates on submerged macrophytes in three Masurian lakes. Ekol. Pol. 23: 371-391.

SoszKa G.J. 1975b: Ecological relations between invertebrates and submerged macrophytes in the lake littoral. Ekol. Pol. 23: $393-415$.
Strayer D.L., Lutz C., Malcom H.M., Munger K. \& Shaw W.H. 2003: Invertebrate communities associated with a native (Vallisneria americana) and an alien (Trapa natans) macrophyte in a large river. Freshwat. Biol. 48: 1938-1949.

TARKOWSKA-KUKURYK M. 2006: Water soldier Stratiotes aloides L. (Hydrocharitaceae) as a substratum for macroinvertebrates in a shallow eutrophic lake. Pol. J. Ecol. 54: 441-451.

TARKOWSKA-KuKURYK M. \& KorniJów R. 2008: Influence of spatial distribution of submerged macrophytes on Chironomidae assemblages in shallow lakes. Pol. J. Ecol. 56: 569-579.

TeR BraAk C.J.F. \& Šmilauer P. 1998: Canoco for Windows: Software for Canonical Community Ordination (version 4). Microcomputer Power, New York.

Tessier C., Cattaneo A., Pinel-Alloul B., Hudon C. \& BorCARD D. 2008: Invertebrate communities and epiphytic biomass associated with metaphyton and emergent and submergent macrophytes in a large river. Aquat. Sci. 70: $10-20$.

TOKESHI M. \& PINDER L.C.V. 1985: Microhabitats of stream invertebrates on two submersed macrophytes with contrasting leaf morphology. Holarctic Ecol. 8: 313-319.

Tóth A., Braun M., Dévai Gy. \& Nagy S. 1998: [Sediment characteristics of the ox-bow Nagy-morotva at Rakamaz: implications for dredging.] Hidrol. Közl. 78: 375-376 [in Hungarian].

Trivinho-Strixino S., Correia L.C.S. \& Sonoda K. 2000: Phytophilous Chironomidae (Diptera) and other macroinvertebrates in the ox-bow Infernão lake (Jataí Ecological Station, Luiz Antônio, SP, Brazil). Rev. Brasil. Biol. 60: 527-535.

VallenduUK H.J. 1999: Key to the Larvae of Glyptotendipes Kieffer (Diptera, Chironomidae) in Western Europe. Privately published, Lelystad, $46+10$ pp.

Vallenduuk H.J. \& Moller Pillot H.K.M. 2002: Key to the Larvae of Chironomus in Western Europe. Privately published, Lelystad, $20 \mathrm{pp}$.

van den Berg M.S., Coops H., Noordhuis R., van Schie J. \& SimON J. 1997: Macroinvertebrate communities in relation to submerged vegetation in two Chara-dominated lakes. Hydrobiologia 342/343: 143-150.

Wiederholm T. 1983: Chironomidae of the Holarctic region. Keys and diagnoses. Part 1. Larvae. Entomol. Scand. Suppl. 19: $1-457$.

Received September 26, 2011; revised and accepted November 18, 2011 